\title{
Factors Affecting Consumption of Edible Oil in Pakistan
}

\author{
Zaryab Ali, Manan Aslam* and Shafqat Rasool \\ Institute of Business Management Sciences, University of Agriculture, Faisalabad, Pakistan
}

\begin{abstract}
The present study identifies major factors affecting consumption of edible oil in Pakistan. Data was collected from the primary. Edible oil industry has grown an impressive rate in Pakistan over the last three decades. Despite an increase in the domestic production a large portion of foreign exchange is still spent on the import of edible oil. Edible oil is main component of the food in Pakistan and is a key ingredient of household food consumption. Many factors affecting consumption of edible oil in Pakistan include: Increase in income, population growth, urbanization, brands liking and disliking. The results from the primary data suggested that price, income, family size and monthly income significantly affected consumption function of ghee and oil. It is suggested that edible oil prices should be reduced to a certain level so that fair majority of people residing in the country may also use in their food stuff as it is better from the health point of view.
\end{abstract}

Keywords: Edible Oil, Population Growth, Urbanization, Consumption function.

\section{Introduction}

In Pakistan agriculture sector plays a vital role in the development of economy. It is the second largest sector contributing over 21 percent of Gross Domestic Product (GDP) and absorbs 45 percent of the country's total labor force. On the other hand, agriculture sector is the main source and supplier of the raw food and nonfood material to other sectors Agriculture contributes in Pakistan's export and attracts largest market share for industrial products such as pesticides, fertilizer, agricultural machinery and implements. Almost 62 percent population of the Pakistan lives in rural areas and is directly or indirectly involved in agriculture sector (GOP, 2011).

In Pakistan, during 2008-09 the total available oil was 2.821 million tons and the production of edible oil at domestic level was around 684 thousand tons, contributing 24 percent of the total availability of oil. The remaining 76 percent of total availability was fulfilled through imports. Similarly, in 2009-10, 1.246 million tons edible oil was imported and the local production was estimated around 0.680 million tons. The total availability of oil from all sources was estimated around 1.749 million tons. In 2009-10, the total cultivated area of major oilseed crop was 9,091 thousand acres (GOP, 2010).

Edible oil is the main component of our kitchen because people specially prefer it for cooking food. Fats and oils are essential dietary requirements of human body. Food items such as meat, dairy products, poultry, fish and nuts are principal and complementary sources of fats and oils in our daily routine. Major contribution of vegetable oil is accomplished by soybeans, sunflower, corn, cottonseed and peanuts. Palm, olives and coconut are also essential sources of oil. Mostly oil is utilized in salad and in cooking applications such as baking, frying etc (Hui, 1996).

Pakistan is the third largest importer of edible oil in the world. Edible oil is mainly supplied through three main sources; oilseeds produced domestically in Pakistan, from imports of refined edible oil and local oil production from imported oilseeds. There is a dire deficiency in production of edible oil in Pakistan. Due to this deficiency, large amount of foreign exchange is utilized on the imports of edible oil which results in the drainage of foreign exchange reserves. Large amount of imports of edible oil are outcome of slower growth of output as compared to sharp increase in demand, rapid growth in population, low oil prices, rising incomes, competition from High Yielding Varieties (HYV) of others crops, non-availability of inputs at proper time, inefficiency of harvesting, inefficient oil extraction plant and smuggling of refined edible oil around the boarders (Chaudary et al., 1998).

All over the world including Pakistan, dietary habits are changing rapidly. People are becoming very conscious to consume low cholesterol and low fat edible oils rather than unsaturated fats in their meals. An increase in per capita income along with addition of health awareness is main source of contribution to increased usage of oil. Although Pakistan is an agricultural country there is ineffective and inefficient agri-system to fulfill domestic requirements of edible oil of the country inhabitants (National Management Consultant, 2006).

Various external factors (such as culture, sub-culture, social class, reference groups, family decisions and certain situational determinants) influence consumer's purchase decisions. Due to urbanization and higher level of education and income, people have become more conscious about their diet and shift their consumption pattern to healthier oils particularly in urban areas while in rural areas; awareness level is not much evident (Morelli, 
2008). Consumption of olive oil is more preferred than other edible oils from health view point (Daksha et al., 2010).

An increase in the oil imports was due to slower growth of output with the sharp increase in demand. As a result the import bill of Pakistan has grown at a tremendous rate and become unaffordable. There were many factors which were responsible for this situation included rapid population growth, low oil prices, disincentive pricing, and harvest and post harvest losses, inefficiency of oil extracting plants and smuggling across the borders (Chaudhry et al., 1998). Consumers were willing to pay higher prices for branded over non branded ghee and for corporate brands over cooperative brands. According to their research flavor were the most important quality attribute rather than texture and color showed the negative relation to price. The results implied that reputations were generated by branding and there were the need for cooperatives to enhance their brand equity through marketing and advertising to compete the corporate entities (Deodhar and Intodia, 2001). Consumer's purchasing behavior was affected by quality, health, packaging and prices etc (Gavruchenko et al., 2003). A study was conducted on the behavioral and non-behavioral factors of customers about the two brands (Kashmir and kisan in Pakistan). They analyzed that Kashmir products were more preferred as compared to kisan due to their taste, quality and larger market share (Ahmad et al., 2006). The most important factors that affected the consumption were consumer price, price of substitutes, quantity produced, population, national income and domestic consumption (Abo-Ragab et al., 2009). Palm kernel oil and ground nut oil demand was judged on the basis of consumer income, price of the product and substitution effect. Palm kernel oil was inferior product because the changed price and increase in consumer income had less effect on the demand of palm kernel oil, while the increasing prices resulted in increase of revenue favored the ground nut oil rather than palm kernel oil (Oguoma et al., 2010).

In countries under lowest per capita income category, edible oil has significant proportion in household food expenditures. The impact of changes in demand, supply and prices of edible oil is much greater in lowincome countries (Drewnowski et al., 1997). Low income group people spend a minor amount of their income on food at stores and in restaurants as compared to higher income group people. They get least benefit from subsidies and from sales promotion schemes because their purchasing quantities are low as compared to high income group. Household income, education of head of household, family size and increasing financial constraints are the main factors which affect purchase pattern of a family. If a family head has little capacity to purchase food items, he would like to choose less nutritious, low quality food because he cannot afford better quality products (Kirkpatrick, 2003).

The present study seeks to delineate factors affecting demand of edible oil. The research aims at analyzing consumer's attitude, consumption pattern according to income classes, brand liking and disliking etc. it seeks to offer policy options for government and the stakeholders for challenging future strategies for edible oil industry.

\section{Materials And Methods}

The study is based on primary data collected through a comprehensive pre-tested questionnaire from 150 consumers of Faisalabad city for the year 2012. This is an industrial city so people residing in these cities are mostly large businessmen as well as laborers. So the consumption function of each income group can be seen easily. A statistical technique of regression analysis (double log form) for estimation of demand functions of edible oil and factor analysis to study the consumer preferences of consumption and purchase of products.

\subsection{Demand function of Oil}

Demand function of Oil was estimated by using following model.

$$
\ln \mathrm{O}=\beta_{\mathrm{o}}+\beta_{1} \ln \mathrm{I}+\beta_{2} \ln \mathrm{PO}+\beta 3 \ln \mathrm{lO}+\beta 4 \ln \mathrm{SS}+\beta 5 \ln \mathrm{LDU}+\beta 6 \mathrm{PH}+\mathrm{e}
$$

Where:

$$
\begin{array}{ll}
\mathrm{O} & =\text { Quantity of Oil consumed }(\mathrm{Kg} / \mathrm{month}) \\
\mathrm{I} & =\text { Family income of household }(\mathrm{Rs} / \mathrm{month}) \\
\mathrm{PO} & =\text { Price of Oil }(\mathrm{Rs} / \mathrm{Kg}) \\
\mathrm{SO} & =\text { Share of edible oil expenses in total food expenditure } \\
\mathrm{FS} & =\text { Family size } \\
\mathrm{EDU} & =\text { Education of respondent (Total years of schooling) } \\
\mathrm{PH} & =\text { Profession of the head of the family } \\
\mathrm{ln} & =\text { Natural log } \\
\beta \mathrm{B} & =\text { Intercept of regression } \\
\beta 1 & =\text { Partial elastic ties } \\
\mathrm{e} & =\text { Error term }
\end{array}
$$




\subsection{Demand function of Ghee}

Demand function of Ghee was estimated by using following model.

Where:

$$
\ln \mathrm{O}=\beta_{\mathrm{o}}+\beta_{1} \ln \mathrm{I}+\beta_{2} \ln \mathrm{PG}+\beta 3 \ln \mathrm{SG}+\beta 4 \operatorname{lnFS}+\beta 5 \ln \mathrm{EDU}+\beta 6 \mathrm{PH}+\mathrm{e}
$$

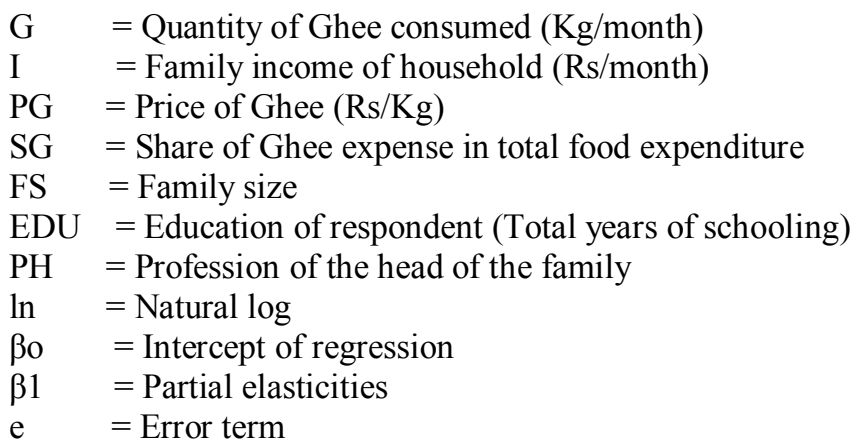

Almost similar variables are affecting the consumption of oil and ghee while the influence some variables are more in demand function rather than other. The dependent variable i.e. Quantity of Oil/Ghee was taken as quantity consumed by a household in $(\mathrm{Kg} / \mathrm{month})$.

\section{Results and Discussion}

The main idea behind estimating the demand function of oil and ghee separately was to identify the major factors that were affecting the consumption of edible oil. This section presents the finding of the regression results: The results of statistical model are discussed separately.

\subsection{Demand function for Oil}

The log of total quantity of oil consumed (LQ) was assumed to be the function of log family income (LI), log of its price (LP), log of share expenses of oil (LSO), log of Family size (LFS), log of Education (LEDU) and profession of head of the family (PH).

$$
\mathrm{LQ}=\mathrm{f}(\mathrm{LI}, \mathrm{LP}, \mathrm{LSO}, \mathrm{LFS}, \mathrm{LEDU}, \mathrm{PH})
$$

Table 1

\begin{tabular}{|c|c|c|c|c|c|c|}
\hline \multirow[b]{2}{*}{ Variables } & \multirow[b]{2}{*}{ Minimum } & \multirow[b]{2}{*}{ Maximum } & \multirow[b]{2}{*}{ Mean } & \multirow{2}{*}{$\begin{array}{c}\text { Std. } \\
\text { Deviation }\end{array}$} & \multicolumn{2}{|c|}{ Collinearity Statistics } \\
\hline & & & & & Tolerance & VIF \\
\hline Quantity of oil & 4 & 20 & 10.23 & 3.690 & - & - \\
\hline Income & 15,000 & 700,000 & 60300.00 & 109120.775 & .376 & 2.658 \\
\hline Price & 150 & 831 & 196.95 & 104.274 & .925 & 1.081 \\
\hline $\begin{array}{l}\text { Share of oil } \\
\text { expenses }\end{array}$ & 2.50 & 31.25 & 12.1795 & 6.83259 & .417 & 2.397 \\
\hline Family size & 4 & 14 & 7.35 & 3.000 & .707 & 1.414 \\
\hline $\begin{array}{l}\text { Education of } \\
\text { Respondent }\end{array}$ & 2 & 18 & 11.33 & 4.560 & .629 & 1.589 \\
\hline
\end{tabular}

Model summary for oil

(Source: Author's own estimations)

To explore the relationship between dependent and independent variables, OLS (Ordinary Least Square Technique) was employed. Double log form was used as values of coefficient in the simple linear regression model were found high. Data collected from respondents on income and food expenditures were in thousand rupees. Double log model gave better interpretation. The strength of the association between the dependent and independent variables is determined by using coefficient of determination i.e. $\mathrm{R}^{2}$. The value of coefficient of determination determines the proportion of total variation in the dependent variable explained by independent variable (Gujrati, 2005). Significance of coefficients was tested separately by using t-statistics at 1 percent, 5 percent and 10 percent level of significance. To interpret the effect of coefficients on the dependent variable, all other variables considered constant.

Descriptive statistics were used to describe the data of dependent variable i.e. quantity of oil consumed and independent variables i.e. family income, price, share of oil expenses, family size, education of respondents and profession of head of the family. The summary statistics is given in table 1. Collinearity is the undesirable situation where the correlations among the independent variables are strong. Tolerance is a static used to determine how much the independent variables are linearly related to one another. Variance Inflating Factor (VIF) is the reciprocal of the tolerance. Large values of VIF are indicator of multicollinearity. If the value of VIF is greater than 10 then the problem of multicollinearity exists. In the research analysis all the values of VIF are less than 10 which explain that there was no multicollinearity in the data. 
The value of $\mathrm{R}^{2}$ was 0.528 which showed that 52 percent variation in the dependent variable caused by the independent variables whereas the remaining variation explained by other unknown variables. Adjusted $\mathrm{R}^{2}$ was used because it took into account both the number of observations and number of variables. For estimated model coefficient of determination was 0.443 which reflected that 44 percent of variation in the dependent variable was explained by independent variable. This much value is quite reasonable for cross-sectional data.

The goodness of fit of the model is further reinforced by the value of F- statistics. For the oil model, value of Ftest was 6.160 which was significant at 1 percent level of significance. This value suggested that the strength of significance of association was appropriate for the above mentioned model.

The coefficient of income was positive with elasticity coefficient of 0.297 percent and significance level of 1 percent, which means that 1 percent increase in income led to 0.297 increases in quantity consumed. Consumption of oil is was largely dependent on income. The prices of oil are higher as compared to its substitutes. Due to which people of higher income preferred to consume it rather than the people of lower income group.

Price is considered as the most important factor that affects the consumption of the households (Hatirli et al., 2004). Value of the estimated coefficient illustrated that there was negative relationship between price of oil and its consumption. As such, 1 percent increase in the price would result .30 percent decrease in the consumption. The highly elastic coefficient was not significant at maximum allowed limit of 10 percent and coefficient of price was found to be 0.116 . This suggests that consumption of oil is a necessity, so increase in price has less effect on its consumption.

The share of oil expenses is an important variable in total food expenditures. It is directly related to quantity consumed. The coefficient of share of oil was positive with elasticity coefficient of 0.455 percent and was highly significant at 1 percent level of significance.

Food expenditure and household size had positive correlation (Gibson, 2002). Family size was the major factor which affected the consumption of household. The number of a person in a family increases the quantity consumed by the household also increases. Result presented in the table 2 showed that 1 percent increase in the family size would increase the .422 percent increase in consumption of oil and was found statistically significant at 1 percent significant level.

Education creates awareness among the people in the usage of products. The coefficient of education was positively related to oil consumption but was not significant in the analysis. The elasticity coefficient of education of the respondent was found to be .038 percent and was non- significant.

Profession of the family head also shows some relevance in their purchase selection. In the analysis the coefficient of elasticity of this variable is positive having value of .070 percent but insignificant.

Table 2

Demand function for oil

\begin{tabular}{|c|c|c|c|c|}
\hline \multirow[b]{2}{*}{ Variables } & \multicolumn{2}{|c|}{ Coefficients } & \multirow[b]{2}{*}{$\mathbf{T}$} & \multirow[b]{2}{*}{ Sig. } \\
\hline & B & Std.Error & & \\
\hline (Constant) & -1.319 & 1.692 & -.780 & .441 \\
\hline LI & .297 & .099 & 2.990 & $.005^{*}$ \\
\hline LP & -.300 & .186 & -1.616 & $.116^{\mathrm{NS}}$ \\
\hline LSO & .455 & .121 & 3.763 & $.001 *$ \\
\hline LFS & .422 & .136 & 3.100 & $.004 *$ \\
\hline LEDU & .038 & .100 & .381 & $.705^{\mathrm{NS}}$ \\
\hline $\mathrm{PH}$ & .070 & .132 & .533 & $.598^{\mathrm{NS}}$ \\
\hline R-Square & \multicolumn{4}{|c|}{0.528} \\
\hline Adjusted R-Square & \multicolumn{4}{|c|}{0.443} \\
\hline F-Test & \multicolumn{4}{|c|}{$6.160^{*}$} \\
\hline
\end{tabular}

Note: NS Denotes Non-Significant

(Source: Author's own estimations)

* Denotes Significant at 1 percent level

\subsubsection{Demand function for Ghee}

As defined in chapter 3, the log of total quantity of ghee consumed (LQ) was assumed to be the function of log Family income (LI), log of its price (LPG), log of share expenses of Ghee (LSG), log of Family size (LFS), $\log$ of Education (LEDU) and profession of head of the family (PH).

$$
\mathrm{LQ}=\mathrm{f}(\mathrm{LI}, \mathrm{LPG}, \mathrm{LSG}, \mathrm{LFS}, \mathrm{LEDU}, \mathrm{PH})
$$


Table 3

Model summary for ghee

\begin{tabular}{|c|c|c|c|c|c|c|}
\hline \multirow[b]{2}{*}{ Variables } & \multirow[b]{2}{*}{ Minimum } & \multirow[b]{2}{*}{ Maximum } & \multirow[b]{2}{*}{ Mean } & \multirow[b]{2}{*}{$\begin{array}{c}\text { Std. } \\
\text { Deviation }\end{array}$} & \multicolumn{2}{|c|}{ Collinearity statistics } \\
\hline & & & & & Tolerance & VIF \\
\hline Quantity of ghee & 3 & 30 & 10.71 & 4.377 & - & - \\
\hline Income & 5,000 & 700,000 & 47949.37 & 95892.688 & .263 & 3.798 \\
\hline Price & 42 & 190 & 165.57 & 18.040 & .946 & 1.057 \\
\hline $\begin{array}{l}\text { Share of ghee } \\
\text { expenses }\end{array}$ & 2.50 & 70.00 & 17.2941 & 11.40148 & .332 & 3.015 \\
\hline Family size & 2 & 17 & 7.19 & 2.944 & .920 & 1.087 \\
\hline $\begin{array}{l}\text { Education of the } \\
\text { Respondent }\end{array}$ & 1 & 18 & 8.61 & 4.965 & .624 & 1.602 \\
\hline
\end{tabular}

(Source: Author's own estimations)

The output of multiple regression model has shown that the overall model was good presentation of the demand function for ghee. $\mathrm{R}^{2}$ value was 0.640 which suggested that more than half of the variation in the consumption of ghee has been explained by the explanatory variables used in the regression model. The F-test is significant at 1 percent level of significance having value of 21.361. VIF values further suggested the absence of muticollinearity among the explanatory variables (Table 4).

The coefficient of income was significant at 1 percent having t value of 6.826 , coefficient of elasticity of .406 , which suggested that one percent increase in income was followed by .406 percent increase in the consumption of quantity of ghee.

The price of ghee was insignificant havening negative relation with value -.029 percent with standard error of .023. As ghee is the most important commodity of kitchen and necessity for cooking so its price has insignificant effect on the consumption.

The share of ghee expenses is an important variable in total food expenditures. It is directly related to quantity consumed. The coefficient of share of ghee was positive with elasticity coefficient of .564 percent and was highly significant at 1 percent level of significance. This result led to the conclusion that one percent increase in share of ghee expenses was followed by .564 percent increase in consumption of quantity of ghee.

The coefficient of Family size had t-value of 6.163 with significance level of 0.000 . The coefficient of this variable was highly significant and positive. The value suggested that 6.163 percent quantity of ghee consumed increase with one percent increase in family size.

The value of elasticity of coefficient of education represented that there is positive relationship of this variable with consumption of quantity but its non-significance shows that there is no effect of education on its consumption.

The coefficient of profession of the head of the family had coefficient of elasticity of .070 percent with significance level of .493 . The coefficient for this variable was positive but highly insignificant.

Table 4

Demand function for ghee

\begin{tabular}{|c|c|c|c|c|}
\hline \multirow[b]{2}{*}{ Variables } & \multicolumn{2}{|c|}{ Coefficients } & \multirow[b]{2}{*}{$\mathbf{T}$} & \multirow[b]{2}{*}{ Sig. } \\
\hline & B & Std.Error & & \\
\hline (Constant) & -4.204 & .743 & -5.658 & .000 \\
\hline LI & .406 & .059 & 6.826 & $.000 *$ \\
\hline LPG & -.029 & .023 & -1.260 & $.212^{\mathrm{NS}}$ \\
\hline LSG & .564 & .078 & 7.212 & $.000 *$ \\
\hline LFS & .456 & .074 & 6.163 & $.000 *$ \\
\hline LEDU & .068 & .050 & 1.365 & $.176^{\mathrm{NS}}$ \\
\hline $\mathrm{PH}$ & .070 & .102 & .689 & $.493^{\mathrm{NS}}$ \\
\hline R-Square & \multicolumn{4}{|c|}{0.640} \\
\hline Adjusted-Square & \multicolumn{4}{|c|}{0.610} \\
\hline F-Test & \multicolumn{4}{|c|}{$21.361^{*}$} \\
\hline
\end{tabular}

(Source: Author's own estimations)

Note: $\quad{ }^{\text {NS }}$ Denotes Non-Significant

* Denotes Significant at 1 percent level

\section{Conclusion}

Edible oil is a regular part of our diet. Consumption pattern for oil is rapidly changing in Pakistan. In the study two models were estimated for demand function. In demand function of oil income, share expenditures oil and family size was significantly affecting the consumption of edible oil. The effect of price was negative but insignificant. In demand function of ghee income, family size, share expenditure of ghee, were significantly affecting consumer choice for ghee. Education and profession of the head of the family were insignificant for 
the consumption of ghee. It is recommended that domestic production of oilseed crop may be enhanced by using canola and sunflower which are substitutes of banaspati ghee having palm oil as an essential ingredient is the better option for reducing imports. Domestic production of palm oil should be increased as it is the main ingredient of banaspati ghee. From the research analyzed that majority of the population used ghee in the cooking in Pakistan. Prices of edible oil should be lowered so that poor people can also use it in their meals as it is better from health point of view. There should be some policy options especially for the needy people to get their food commodities at reasonable prices.

\section{References}

[1] GOP, Economic survey of Pakistan (2010-2011), Government of Pakistan, Economic advisor's wing, Ministry of Finance, Islamabad, Pakistan, 2011

[2] GOP, Economic survey of Pakistan (2009-2010), Government of Pakistan, Economic advisor's wing, Ministry of Finance, Islamabad, Pakistan, 2010.

[3] H. Y. Hui, Bailey's industrial oil and fat products $5^{\text {th }}$ Edition (New York, USA: Wiley Inter Science Publications, 1996)

[4] G. M. Chaudhry, A. Mahmood, and G. M. Chaudhry, Pakistan's edible oil needs and prospects of self sufficiency, Pakistan Development Review, 37(4), 1998, 205-216.

[5] National Management Consultants, Framing of edible oil seeds, production of edible oils, processing and marketing, Employment and research section, planning and development division, Government of Pakistan, Islamabad, 2006.

[6] G. Morelli, Edible oil in Pakistan: An overview with a focus on olive oil (Florence, Italy: Nova Arti Grafiche Publisher, 2008).

[7] A. Daksha., P. Jaywant., C. Bhagyashree and P. Subodh, Estimation of sterols content in edible oil and ghee samples, Electronic Journal of Environmental, Agricultural and Food Chemistry, 9(10), 2010, 1593-1597.

[8] Y. S. Deodhar, and V. Intodia, Quality attributes and hedonic price analysis of ghee, The Consumer Magazine. 21, $2001,6-13$.

[9] T. Gavruchenko, G. Baltas, C. Fotis and S. Hadjidakis, Comparative marketing strategies for organic olive oil: The case of Greece and Holland, Cahiers Options Méditerranéennes, 61, 2003, 247-255.

[10] W. Ahmad, K. Mustafa, and T. Ahmad, Factors influencing customer's preference for purchase of vegetable ghee: A comparison of two ghee firm in Punjab, Journal of Agricultural Science, 43, 2006, 1-2.

[11] S. A. S. Abo-Ragab, A. R. S. Hany, and S. S. Essam, Factors affecting the production and consumption of olive oil in Egypt, Journal of Applied Science Research, 5(10), 2009 1535-1546.

[12] O. N. N. Oguoma, N. C. Ehirim., G. N. Benchendo., I. Nnadi. and E. N. Okoronkwo, Determinants of aggregate household demand for edible oils in Imo State, African Journal of Agricultural Research, 5(15), 2010, 1932-1936.

[13] A. Drewnowski, and B. M. Popkin, The nutrition transition: New trends in the global diet, Nutrition reviews, 55(2), 1997, $31-43$.

[14] S. Kirkpatrick, and V. Tarasuk, The Relationship between low income and household food expenditure patterns in Canada, Public Health Nutrition. 6(6), 2003, 589-597.

[15] N. D. Gujarati, Basic Econometrics $4^{\text {th }}$ edition (New York: Mc Graw- Hill, 2003).

[16] A. S. Hatirli, B. Ozkan and A. R. Aktas, Factors affecting fluid milk purchasing source in Turkey, Food quality and preference $15(6),(2004), 509-515$.

[17] J. Gibson, Why does the engel model work? Food demand, economies of size and household survey methods, Oxford Bulletin of Economics and Statistics, 64(4), 2002, 341-359. 